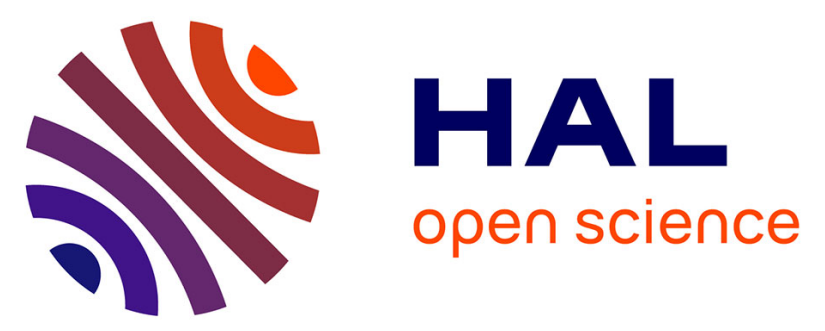

\title{
Synthesis and Characterization of a Series of Ruthenium Tris( $\beta$-diketonato) Complexes by an UHV-STM Investigation and Numerical Calculations
}

Sabrina Munery, Nicolas Ratel-Ramond, Youness Benjalal, Loranne Vernisse, Olivier Guillermet, Xavier Bouju, Roland Coratger, Jacques Bonvoisin

\section{To cite this version:}

Sabrina Munery, Nicolas Ratel-Ramond, Youness Benjalal, Loranne Vernisse, Olivier Guillermet, et al.. Synthesis and Characterization of a Series of Ruthenium Tris( $\beta$-diketonato) Complexes by an UHV-STM Investigation and Numerical Calculations. European Journal of Inorganic Chemistry, 2011, 2011 (17), pp.2698 - 2705. 10.1002/ejic.201100116 . hal-01737022v2

\section{HAL Id: hal-01737022 \\ https://hal.science/hal-01737022v2}

Submitted on 19 Mar 2018

HAL is a multi-disciplinary open access archive for the deposit and dissemination of scientific research documents, whether they are published or not. The documents may come from teaching and research institutions in France or abroad, or from public or private research centers.
L'archive ouverte pluridisciplinaire HAL, est destinée au dépôt et à la diffusion de documents scientifiques de niveau recherche, publiés ou non, émanant des établissements d'enseignement et de recherche français ou étrangers, des laboratoires publics ou privés. 


\title{
Synthesis and characterization of a series of ruthenium tris( $\beta$-diketonato) complexes with UHV-STM investigation and numerical calculations
}

\author{
Sabrina Munery, ${ }^{[\mathrm{a}]}$ Nicolas Ratel-Ramond, ${ }^{[\mathrm{a}]}$ Youness Benjalal, ${ }^{[\mathrm{a}]}$ Loranne Vernisse ${ }^{\text {[a] }}$ Olivier \\ Guillermet, ${ }^{[\mathrm{a}]}$ Xavier Bouju, ${ }^{[\mathrm{a}]}$ Roland Coratger ${ }^{[\mathrm{a}]}$ and Jacques Bonvoisin ${ }^{[\mathrm{a}] *}$
}

Keywords: Ruthenium, $\beta$-diketonato complex, mixed-ligand, X-Ray structure, low Temperature STM

A series of ruthenium tris( $\beta$-diketonate), was investigated using electrochemistry, UV-Vis spectroscopy, ${ }^{1} \mathrm{H}$ and ${ }^{13} \mathrm{C}$ NMR and FAB mass spectroscopy. Several new mononuclear mixed-ligand ruthenium(III) complexes including - dibenzoylmethanate ion $(\mathrm{dbm}) ;[\mathrm{Ru}(\mathrm{dbm}) 3] \mathbf{1}$ - one or two acetylacetonate ion $(2,4-$ pentanedionate, acac-); $\left[\mathrm{Ru}(\mathrm{dbm})_{2}(\mathrm{acac})\right] 2,\left[\mathrm{Ru}(\mathrm{dbm})(\mathrm{acac})_{2}\right] 3$ acetonitrile ligand; $\left[\mathrm{Ru}(\mathrm{dbm})_{2}\left(\mathrm{CH}_{3} \mathrm{CN}\right)_{2}\right]\left[\mathrm{CF}_{3} \mathrm{SO}_{3}\right] \mathbf{4}-$ or functionalized acetylacetonate ion; $\left[\mathrm{Ru}(\mathrm{dbm})_{2}(\right.$ acac-I) $] \mathbf{5}$ (acac-I $=$ 3 -iodo-2,4-pentanedionate ion), $\left[\mathrm{Ru}(\mathrm{dbm})_{2}(\mathrm{acac}-\mathrm{Br})\right] \mathbf{6}($ acac-Br $=$ 3-bromo-2,4-pentanedionate ion) were prepared.
In addition, X-Ray structures for complexes 1, 2, 3, 4 and $\mathbf{6}$ were determined. Scanning tunneling microscopy measurement at liquid He temperature and in ultra high vacuum (UHV-STM) of complex 1 on $\operatorname{Ag}(111)$ surface was conducted. This indicates that the complex can be successfully evaporated and observed after adsorption on a metallic substrate. Analysis of the STM images, supported by adsorption and STM image calculations demonstrates that the molecules exist in two stable forms when adsorbed on the surface. [a] CNRS, CEMES and MANA Satellite, GNS, 29 rue Jeanne Marvig, BP 94347, 31055 Toulouse Cedex 4 Fax: +335622579 99

E-mail: jbonvoisin@cemes.fr

Supporting information for this article is available on the WWW under http://www.eurjic.org/ or from the author.

\section{Introduction}

Coordinated metal ions are the essential centres of chemical activity in a variety of molecules. Beyond any chemical application, metal complexes embedded into supramolecular assemblies are potential building blocks for molecular electronics. ${ }^{[1-8]}$ Therefore, studying the functional molecules on a substrate and investigating their behaviour and properties are a primary requirements for potential applications, since the molecular deformation due to surface interaction plays a crucial role. ${ }^{[9-11]}$ New progress and possibilities in metal complexes for molecular electronics has been reviewed recently, highlighting that the electronic state of metal complexes is attractive for conducting highly integrated, functional molecular components. ${ }^{[12]}$ In recent years, the investigation of the properties of isolated, individual molecules has been greatly facilitated by scanning tunnelling microscopy (STM). Thus, this technique has been used to study the adsorption site and geometry of molecules on surfaces, ${ }^{[9,13]}$ to obtain high resolution images of intramolecular structure, ${ }^{[14-16]}$ to investigate the electronic properties of individual molecules, ${ }^{[17-19]}$ to detect different spin states of transition-metal complexes ${ }^{[20]}$ and to observe charge localization on isolated mixed-valence complexes. ${ }^{[21-23]}$ Recent review also appeared on STM spectroscopy of magnetic molecules. ${ }^{[24]}$ Several studies have been reported on ruthenium compounds measured by STM ${ }^{[25-36]}$ and also on ruthenium and tris(diketonato) ligands, ${ }^{[37-42]}$ but very few on adsorption of ruthenium or metal acetylacetonate (acac) complexes and their derivatives. [43, 44] It is then of interest to synthesize and characterize $\mathrm{Ru}$ complexes including ligands, which favour their evaporation and their adsorption for further investigations using STM and related techniques such as Scanning Tunnelling Spectroscopy. This is the reason why dibenzoylmethanato (dbm) ligand was chosen, mainly because of its propensity to adhere to the substrate due to its phenyl rings. ${ }^{[45,46]}$

In this work, we report the synthesis and characterization of a series of mononuclear ruthenium complexes with $\mathrm{dbm}$ ligands and functionalized or non-functionalized acac ligands. We also present a study of the adsorption of a ruthenium tris( $\beta$-diketonate) at low temperature, i.e. tris dibenzoylmethanato-ruthenium $\left[\mathrm{Ru}(\mathrm{dbm})_{3}\right] \mathbf{1}$ on a $\operatorname{Ag}(111)$ surface by UHV-STM coupled to molecular adsorption calculations and STM image calculations. These calculations have been done to obtain unambiguous information of the adsorption state. Indeed, it is necessary to compare experimental images to theoretical STM ones preceded by molecular mechanics calculations. ${ }^{[11]}$

\section{Results and Discussion}

Series of $\mathrm{Ru}(\mathrm{III})$ tris( $\beta$-diketonato) complexes have been previously synthesized. ${ }^{[37,47,48]}$ Complex $\mathbf{1}$ has already been obtained in $47 \%$ yield by Endo et $a l,{ }^{[47]}$ starting from 'Ruthenium blue solution'. Here, we present a synthesis where the three compounds 1-3 can be obtained in a one pot reaction ( $c f$. scheme 1) starting from ruthenium trichloride, two equivalents of $\mathrm{dbm}$ and one equivalent of acac. Each compound was separated and purified by column chromatography. Complex 2 can also be obtained by another way ( $c f$. scheme 2), but with lower yield, via the preparation of bis(MeCN)bis( $\beta$-diketonato)ruthenium(III) species through a ligand displacement reaction of $\operatorname{tris}(\beta$ diketonato)ruthenium(III) complexes, induced by strong acid. ${ }^{[49,50]}$ The iodination or bromination selectively occurred at the $\gamma$-position of the acac ligand and led to compounds $\mathbf{5}$ and $\mathbf{6}$ with good yield (77 and $89 \%$ ), this was adapted from literature procedure. ${ }^{[51-53]}$ 


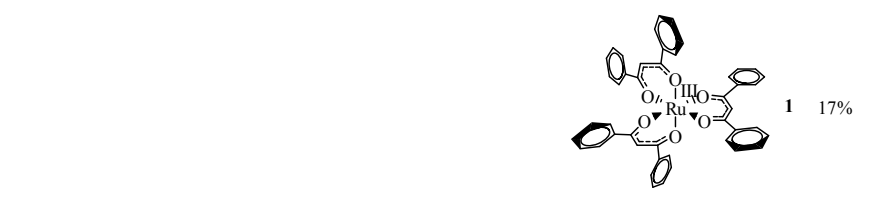

$\mathrm{RuCl}_{3}, x \mathrm{H}_{2} \mathrm{O} \frac{\stackrel{\mathrm{O}}{2}, 1 \prod_{\mathrm{O}} \prod_{\mathrm{O}}, \mathrm{KHCO}_{3}}{\mathrm{H}_{2} \mathrm{O} / \mathrm{EtOH}(25 / 100),}$
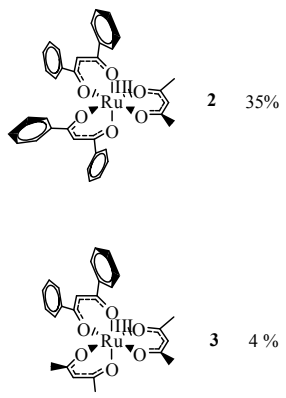

Scheme 1, Synthesis of complexes 1-3
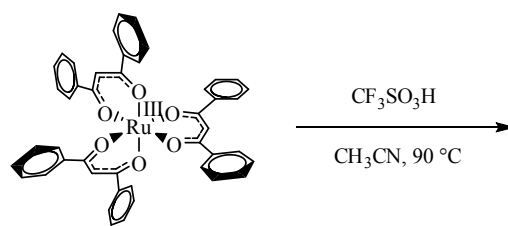

1
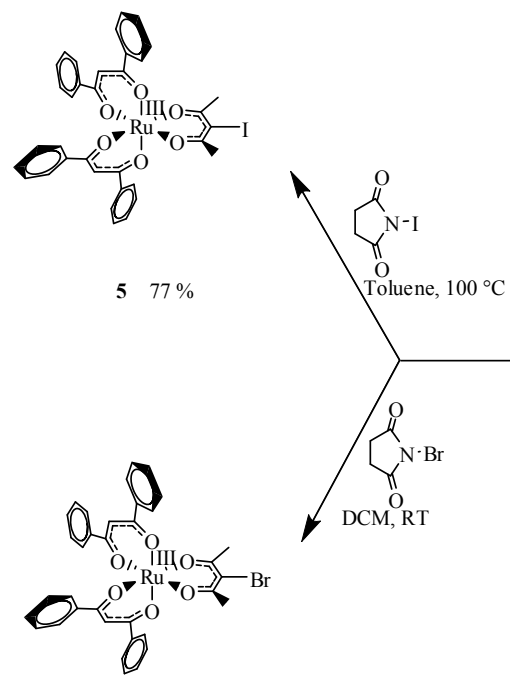

$689 \%$

Scheme 2, Synthesis of complexes 2-5 and 6

Cyclic Voltammetry (CV) data for the complexes 1-6 are given in Table 1 and also in Figure $\mathrm{S} 1$. The $\mathrm{E}_{1 / 2}$ potentials were determined from the average of the anodic and cathodic peaks potentials. All the waves are reversible with peak to peak separation of around $60-80 \mathrm{mV}$. The reversible half-wave potentials $\mathrm{E}_{1 / 2}$ of 5-6 are 50-63 $\mathrm{mV}(76-81 \mathrm{mV})$ more positive than that of $\mathbf{2}$ for the $\mathrm{Ru}^{\mathrm{IV}} / \mathrm{Ru}^{\mathrm{III}}\left(\mathrm{Ru}^{\mathrm{III}} / \mathrm{Ru}^{\mathrm{II}}\right)$ redox couple. These positive shifts of the potentials reflect the electron-withdrawing character of $-\mathrm{I}$ and $-\mathrm{Br}$.

The UV-Vis data are shown in Table 1. Complexes 1-3, 5 and 6 present the same overall shape but differ in intensity ( $c f$. supplementary materials, Figures S5 and S6). They all present three strong bands in the UV-Vis area. One can notice that when going from 1 to $\mathbf{3}$, the transition intensity around $330 \mathrm{~nm}$ decreases successively by a factor of one third. This corresponds to the progressive replacement of $\mathrm{dbm}$ by acac ligand.

NMR experiments have been made on complexes 1-3 and 5, 6 . All the NMR $\left({ }^{1} \mathrm{H}\right.$ and $\left.{ }^{13} \mathrm{C}\right)$ spectra are shown on supplementary materials ( $c f$. supplementary materials, Figures S7-S16). All the ${ }^{1} \mathrm{H}$ and ${ }^{13} \mathrm{C}$ signals were unambiguously assigned on the basis of chemical shifts, spin-spin coupling constants, splitting patterns, and signal intensities, by using ${ }^{1} \mathrm{H}-{ }^{1} \mathrm{H}$ COSY; they are presented in the experimental section for complex 1-3 and 5, 6. Comparison of ${ }^{1} \mathrm{H}$ NMR spectra for complexes $\mathbf{1 ,} \mathbf{2}$ and $\mathbf{6}$ is shown in Figure 1. $\mathrm{Ru}(\mathrm{III})$ complexes often give very broad, poorly resolved ${ }^{1} \mathrm{H}$ NMR signals as a result of rapid nuclear spin relaxation induced by the paramagnetism, but examples of interpretable ${ }^{1} \mathrm{H}$ NMR data for $\mathrm{Ru}(\mathrm{III})$ species have appeared. ${ }^{[37,47]}$ The spectrum of $\left[\mathrm{Ru}(\mathrm{dbm})_{3}\right]$, which has a $\mathrm{D}_{3}$ symmetry, is simple: it consists of four peaks, three for the phenyls protons and one for the methyne protons of the ligands in accordance with the work of Endo et al. ${ }^{[47]}$ The signal of the methyne protons for all the ruthenium(III) complexes appears at very high field region because of the paramagnetism of the ruthenium(III) complexes. On going from complex $\mathbf{1}$ to complex $\mathbf{2}$, all the phenyls protons are doubled due to the loss of symmetry. The $\delta$ values for the Me signals of the coordinated acac ligands reveal an upfield shift (compared to a 'diamagnetic value') due to the interaction with the paramagnetic $\mathrm{Ru}(\mathrm{III})$ centre. It has to be noted that the methyne signal $(\delta=-22.8 \mathrm{ppm})$ of the coordinated acac ligand is less upfield than that of the methyne signals $(\delta=$ $37.0 \mathrm{ppm}$ ) of the dbm ligands. As expected, the methyne signal of the coordinated acac ligand for complex $\mathbf{6}$ no longer occurs.

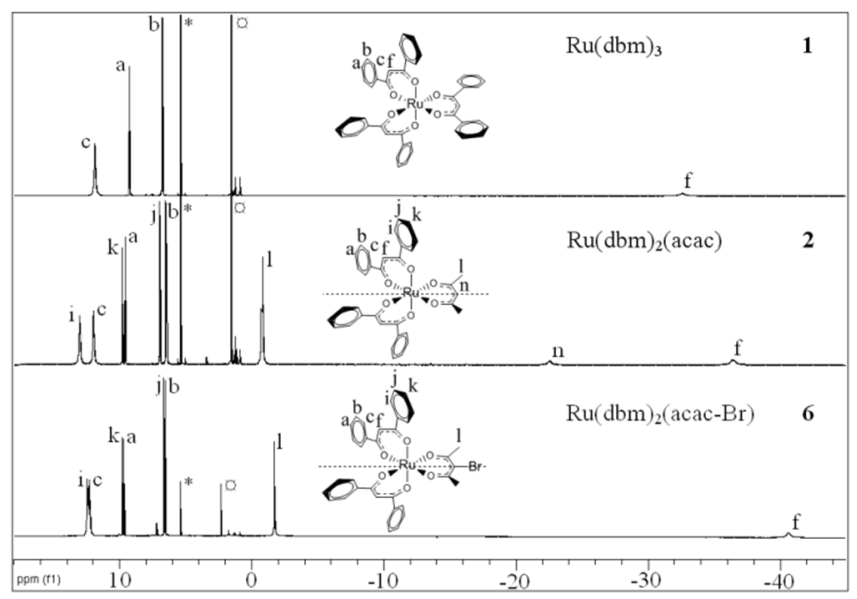

Figure 1. ${ }^{1} \mathrm{H}$ NMR spectra of complexes $\mathbf{1}, 2$ and $\mathbf{6}$ in $\mathrm{CD}_{2} \mathrm{Cl}_{2}$ at r.t. (* and a are respectively due to deuterated solvent and traces of impurities in solvent) 


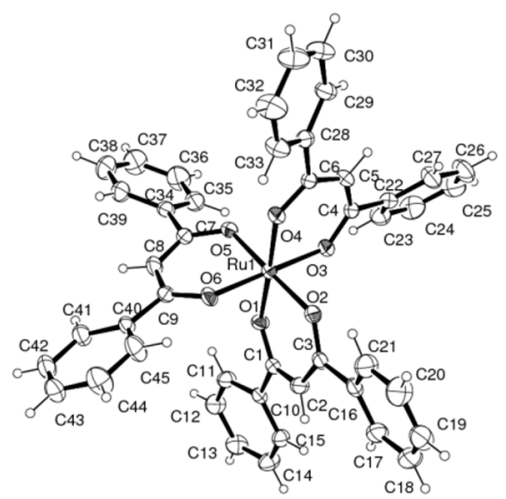

Figure 2. ORTEP drawing of the $\left[\mathrm{Ru}(\mathrm{dbm})_{3}\right] \mathbf{1}(30 \%$ of probability thermal ellipsoids)

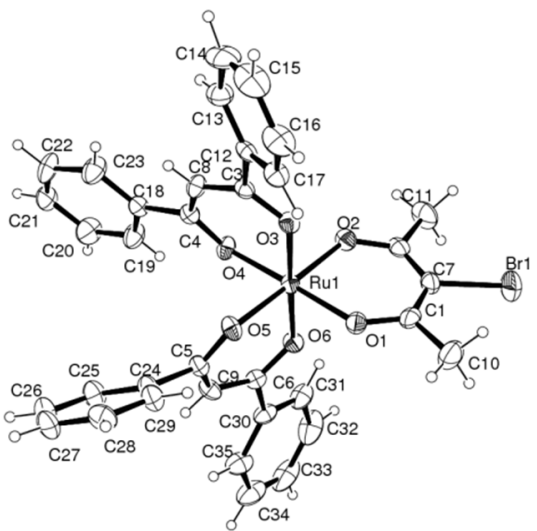

Figure 3. ORTEP drawing of the $\left[\operatorname{Ru}(\mathrm{dbm})_{2}(\mathrm{acac}-\mathrm{Br})\right] \mathbf{6}(30 \%$ of probability thermal ellipsoids).

Crystal structure data for complexes 1-4 and $\mathbf{6}$ are given in Table $\mathrm{S} 1$. Selected bond lengths and angles are reported in Table S2 and S3. Figures 2 and 3 show the ORTEP drawings of $\mathbf{1}$ and $\mathbf{6}$. The Ru$\mathrm{O}$ distances as well as the bond angles are consistent with the ranges of values reported in the literature. ${ }^{[37,54,55]}$

Table 1. UV-Vis and electrochemical data

\begin{tabular}{|c|c|c|c|}
\hline \multirow[t]{2}{*}{ Complex } & \multirow{2}{*}{$\begin{array}{l}\text { UV-Vis data }{ }^{[\mathrm{a}]} \\
\lambda / \mathrm{nm}\left(\varepsilon / \mathrm{M}^{-1} \mathrm{~cm}^{-1}\right)\end{array}$} & \multicolumn{2}{|c|}{ Redox potentials ${ }^{[\mathrm{b}]} \mathrm{E}_{1 / 2} / \mathrm{V}(\Delta \mathrm{E}, \mathrm{V})$} \\
\hline & & $\mathrm{Ru}^{\mathrm{III}} / \mathrm{Ru}{ }^{\mathrm{II}}$ & $\mathrm{Ru}^{\mathrm{IV}} / \mathrm{Ru}{ }^{\mathrm{III}}$ \\
\hline \multirow{3}{*}{1} & $430(12847)$ & & \\
\hline & 330 (48907) & $-0.615(0,068)$ & $1.000(0.076)$ \\
\hline & $258(35503)$ & & \\
\hline \multirow{3}{*}{2} & $415(8761)$ & & \\
\hline & $332(34805)$ & $-0.689(0.073)$ & $0.995(0.076)$ \\
\hline & $258(28077)$ & & \\
\hline \multirow{7}{*}{3} & $504(2240)$ & & \\
\hline & 404 (6524) & & \\
\hline & 335 (20646) & $-0.767(0.078)$ & $0.993(0.081)$ \\
\hline & $262(20635)$ & & \\
\hline & $229(13510)$ & & \\
\hline & $633(1781)$ & & \\
\hline & $388(11862)$ & & \\
\hline
\end{tabular}

\begin{tabular}{llll}
4 & $336(37570)$ & $0.150(0.063)$ & \\
& $263(20931)$ & & \\
& $228(16234)$ & & \\
\hline & $562(2256)$ & & \\
& $414(10569)$ & & \\
$\mathbf{5}$ & $331(36727)$ & $-0.613(0.073)$ & $1.045(0.074)$ \\
& $257(27886)$ & & \\
& $228(23069)$ & & \\
\hline & $556(2417)$ & & \\
& $412(11644)$ & & \\
$\mathbf{6}$ & $331(40967)$ & $-0.608(0.074)$ & \\
& $258(30580)$ & & \\
& $228(22823)$ & & \\
&
\end{tabular}

[a] in $\mathrm{CH}_{2} \mathrm{Cl}_{2}[\mathrm{~b}] \mathrm{Vs} \mathrm{SCE}$, in $\mathrm{CH}_{2} \mathrm{Cl}_{2}, 0.1 \mathrm{M} \mathrm{TBAH}, 0.1 \mathrm{~V} / \mathrm{s}$

\section{STM experiments}

After evaporation of $\left[\mathrm{Ru}(\mathrm{dbm})_{3}\right] 1$ on $\operatorname{Ag}(111)$ held at $4.5 \mathrm{~K}$, the surface is covered with two different objects always presenting the same shape. This shows that the molecules are not destroyed during evaporation since no fragments appear on the substrate while scanning with the STM tip. It should be noted that the general shape of these two forms does not dramatically change in terms of bias voltage in the $-2 \mathrm{~V}$ to $2 \mathrm{~V}$ range. As we will see further, calculations confirm that molecules stay intact on the surface. Three of these objects (labelled 1,2 and 3) are shown in Figure $4 \mathrm{a}$.

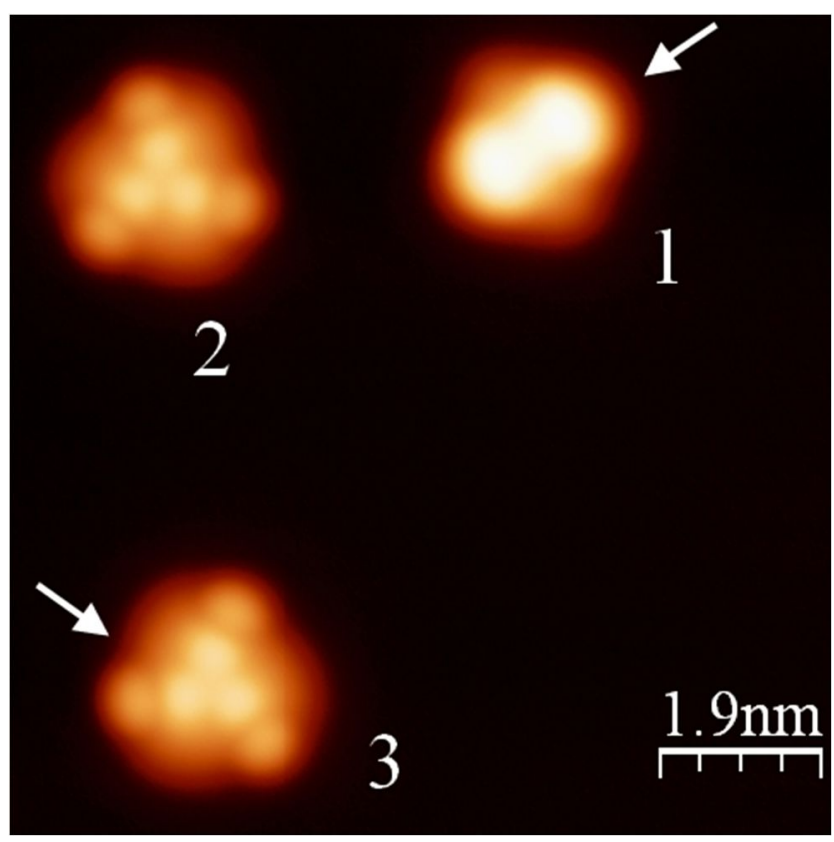

Figure 4a: STM image $\left(9.4 \times 9.4 \mathrm{~nm}^{2}\right)$ of the $\operatorname{Ag}(111)$ surface after evaporation of $\mathrm{Ru}(\mathrm{dbm})_{3}$ on a substrate held at liquid helium temperature (sample bias voltage $1.5 \mathrm{~V}$, tunneling current $15 \mathrm{pA}, \mathrm{T}=4.5 \mathrm{~K}$ ). The two arrows indicate the directions in which the cross sections in Fig. $4 \mathrm{~b}$ and $4 \mathrm{c}$ have been performed 
In type (1), the molecule exhibits a two-lobed structure with an apparent height of about $3.9 \AA$ ( $c f$ Figure $4 \mathrm{~b}$, red curve). The two protrusions are separated by about $0.87 \mathrm{~nm}$ while the overall size of the molecule is $1.92 \mathrm{~nm}$. Two small corrugations also appear on the sides of the main protrusions giving an apparent square-shape to the structure in 'contact' with the surface. The two other objects present a different structure. A central three-lobed structure is surrounded by three smaller bumps, each of them making an angle of 25 degrees with respect to the threefold axes of symmetry imposed by the central core. The objects (2) and (3) differ by the fact that the rotation of the peripheral groups is anti-clockwise in (2) and clockwise in (3), which reveals the chiral character of these adsorbates on the surface.

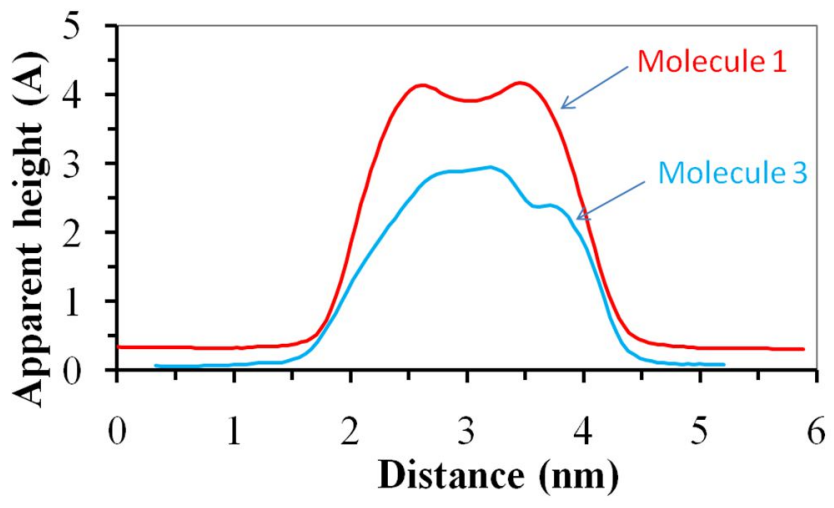

Figure 4b: Cross sections along molecule 1 and molecule 3 showing an apparent height above the $\operatorname{Ag}(111)$ surface of about $3.9 \AA$ and $2.9 \AA$ respectively. Red curve has been vertically shifted for clarity.

The cross section presented in Figure $4 \mathrm{~b}$ (blue curve) shows that the apparent height is about $2.89 \AA$ (in these tunnelling conditions) while the lateral size is $2 \mathrm{~nm}$. The corrugation of the peripheral groups is $0.55 \AA$ below the central part of the molecule. A racemic mixture of species (2) and (3) has been observed on the substrate meaning that the adsorption process is not enantio-selective for this molecule on the (111) substrate. One has to notice that these racemic forms represent about $20 \%$ of the total imaged molecules.

\section{Adsorption and STM images calculations}

The adsorption for the $\mathrm{Ru}(\mathrm{dbm})_{3}$ molecule was carried out with an extended semiempirical atom superposition and electron delocalization (ASED+) approach. ${ }^{[56]}$ Standard parameters for carbon, hydrogen, and oxygen were used. The $\left(\mathrm{H}_{\mathrm{ii}}, \zeta\right)$ extended Hückel parameters for $\mathrm{Ru}$ were chosen as $\mathrm{Ru} 5 \mathrm{~s}(-8.6,2.078), \mathrm{Ru}$ $5 \mathrm{p}(-3.28,2.043)$, and $\mathrm{Ru} 4 \mathrm{~d} \mathrm{H}_{\mathrm{ii}}=-11.12 \mathrm{eV}, \zeta_{1}=5.378$ and $\zeta_{2}=$ 2.303 with weighting coefficients of 0.534 and 0.6365 respectively following Hoffmann et al. ${ }^{[57]}$ After relaxation of the molecule geometry on the surface, two different structures were found. It is notable that the optimization procedure was carried out with a number of starting positions in order to accurately investigate the adsorption potential energy surface.

In the first structure (Figure 5), the two dbm groups were placed parallel to the plane of the $\operatorname{Ag}(111)$ surface. After relaxation with ASED+, the molecular structure exhibits two phenyl rings rather perpendicular to the surface plane (Fig. 5b). The adsorption energy was found to be $0.60 \mathrm{eV}$ with all the atoms closest to the surface being at a height of $2.5 \mathrm{~A}$. In the second structure (Figure 6), the molecule was placed on the surface with three phenyl groups exhibiting an octahedral geometry and with each oxygen atom above a hollow site on the $\operatorname{Ag}(111)$ surface. The relaxed structure is shown in Fig. $6 \mathrm{~b}$ where all the atoms closest to the surface being at a height of $2.5 \AA$. The adsorption energy including the van der Waals interaction between the molecule and the metallic surface reaches $0.34 \mathrm{eV}$.
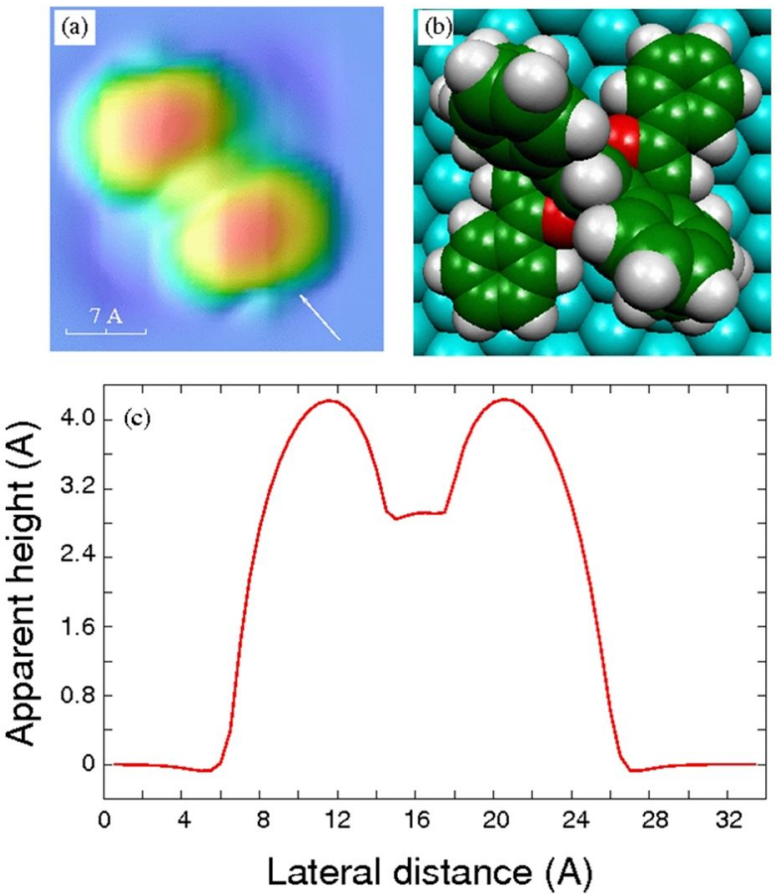

Figure 5: (a) EHMO-ESQC calculated image of $\mathrm{Ru}(\mathrm{dbm})_{3}$ molecule adsorbed on $\operatorname{Ag}(111)$ under the same tunneling conditions as in experimental STM. (b) Space-filling model of $\mathrm{Ru}(\mathrm{dbm})_{3}$ adsorbed on Ag(111). (c) Profile showing the calculated apparent height (4.22 $\AA$ ) of the molecule shows the two bright protrusions are separated by about $9 \AA$.
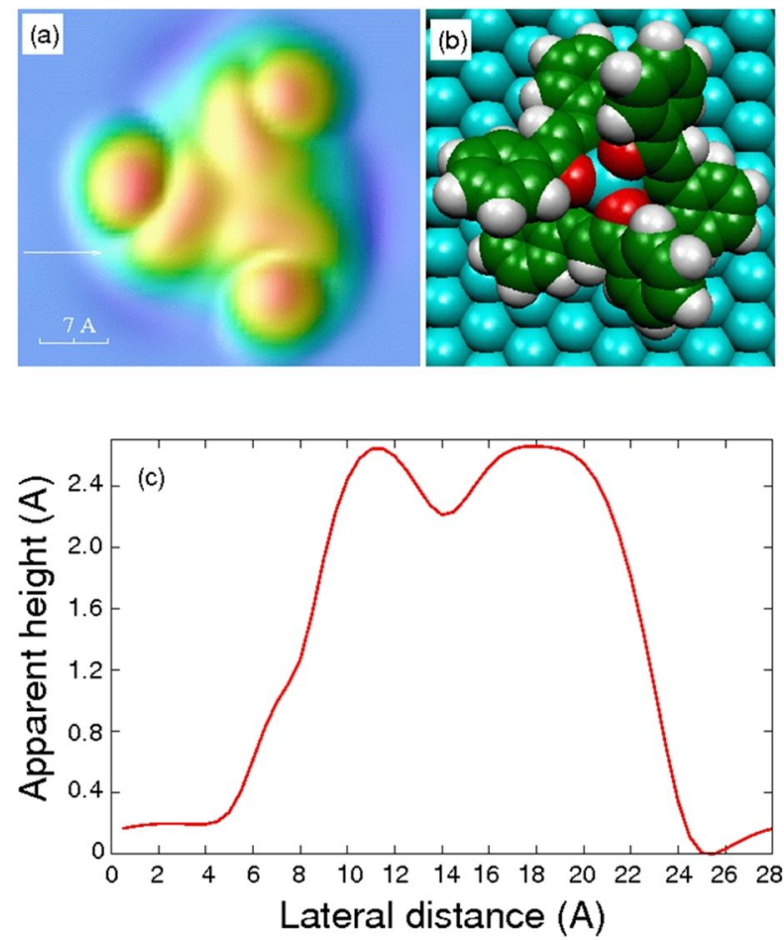

Figure 6: (a) EHMO-ESQC calculated image of $\mathrm{Ru}(\mathrm{dbm})_{3}$ adsorbed on $\operatorname{Ag}(111)$ under the same tunneling conditions as in experimental STM. (b) Space-filling model of $\mathrm{Ru}(\mathrm{dbm})_{3}$ adsorbed on $\mathrm{Ag}(111)$. (c) Profile showing the calculated apparent height of the $\mathrm{Ru}(\mathrm{dbm})_{3}$ molecule with respect to the $\operatorname{Ag}(111)$ surface $(2.66 \AA)$ as indicated by arrow in (a). 
Adsorption calculations give two stable conformations, the twolobed structure being privileged. This is in good agreement with the statistical experimental results. What is interesting to highlight is that the central cage around the $\mathrm{Ru}$ atom is not distorted in the two forms. Indeed, among all the starting configurations we tried, it appears that the stability of the central octahedral site is a key point for the final conformation. Moreover, we were not able to characterise the energy barrier between the two final adsorption states due to the large number of degrees of freedom of the molecule.

The STM images of a $\mathrm{Ru}(\mathrm{dbm})_{3}$ molecule were calculated with the elastic quantum chemistry scattering technique (ESQC) ${ }^{[58]}$ under the same tunnelling condition as in STM experiments. The calculated results displayed in Figures (5 and 6) are consistent with the experimental results. This corroborates the fact that the molecules are not destroyed during the deposition process.

As already found with Lander molecules, the contrast in the STM images is governed by the topmost phenyl rings modulated by the presence of the oxygen atoms underneath. ${ }^{[13,59]}$

This suggests that the two forms observed in the STM images result from two different adsorption geometries due to the peculiar 3D structure of complex 1.

\section{Conclusions}

Ruthenium complexes have been characterized using electrochemistry, UV-Vis spectroscopy, ${ }^{1} \mathrm{H}$ and ${ }^{13} \mathrm{C}$ NMR and FAB mass spectroscopy. With the main objective to synthesize compounds with magnetic and electron transport properties, single $\left[\mathrm{Ru}(\mathrm{dbm})_{3}\right]$ molecules have been observed by Low Temperature STM. The STM images as well as the calculations indicate that the molecules exhibit two different adsorption geometries on the $\operatorname{Ag}(111)$ surface and that their stability can be attributed to the dbm ligand interacting with the substrate. More generally, these results show that this type of compound can be used for experiments in which single larger Ru complex would be studied and manipulated using the special properties of STM for potential applications in the field of quantum computation. Moreover, it opens the route to the physics of the Kondo effect at the single molecule scale for instance, ${ }^{[60-62]}$ in particular due to the presence of the $\mathrm{Ru}(\mathrm{III})$ paramagnetic centre, or to studies dedicated to the magnetic information transfer through molecular adlayer or molecular wire. ${ }^{[63-65]}$

\section{Experimental Section}

Materials. All chemicals and solvents were of reagent grade or better. The complexes were purified by column chromatography using Silica gel 60 (Merck or Agela). Elemental analyses were performed by the 'Service de microanalyse ICSN-CNRS Gif/Yvette'.

Physical Measurements. UV-Visible spectra were recorded on a Varian Cary 5000 spectrophotometer. Cyclic voltammograms were obtained with an Autolab system (PGSTAT100) in $\mathrm{CH}_{2} \mathrm{Cl}_{2}(0.1 \mathrm{M}$ tetrabutylammonium hexafluorophosphate, TBAH as supporting electrolyte) at $25^{\circ} \mathrm{C}$. A three electrode cell was used comprising a $1 \mathrm{~mm}$ Pt-disk working electrode, a Pt wire auxiliary electrode, and an aqueous saturated calomel (SCE) reference electrode. Mass spectra were recorded by the 'Service de Spectroscopie de Masse' of Paul Sabatier University using FAB (Nermag R10-R10, NBA matrix) in positive mode. 1H NMR spectra were taken on Bruker Avance $300 \mathrm{MHz}$ and $500 \mathrm{MHz}$ equipment in $\mathrm{CD}_{2} \mathrm{Cl}_{2}$.

STM Studies. STM experiments have been performed at $\mathrm{T}=4.5 \mathrm{~K}$ on an ultra-high vacuum STM (LT-Omicron) with a base pressure of $1.5 .10^{-11}$ mbar. The Ag (111) crystal is cleaned by repeated Ar+ bombardment cycles followed by annealing at $810 \mathrm{~K}$. The molecules are evaporated from a 0.15 mm tungsten filament submitted to high temperature outgassing cycles before the evaporations. These latter have been conducted while the substrate was held at liquid helium temperature, i.e. directly on the STM head. In this case, the vacuum never exceeds $1.4 .10^{-10}$ mbar in the STM chamber. Tips made of $200 \mu \mathrm{m}$ diameter tungsten wires are prepared by electrochemical etching in a $1 \mathrm{M}-\mathrm{NaOH}$ solution and are cleaned in the UHV preparation chamber using direct current heating. All the STM images presented in this paper are given without any data processing.

X-ray diffraction studies. All the crystals were obtained either by slow evaporation of a solution of $\mathrm{CH}_{2} \mathrm{Cl}_{2} /$ pentane (for $\mathbf{1 , 2}$ and 4) or precipitation at low temperature (for $\mathbf{3}$ and 6). Suitable crystals were first selected under a binocular and then mounted onto a goniometer head using cyanolite. The diffraction data were collected using an Enraf Kappa-CCD automatic XRay single crystal diffractometer, using $\operatorname{MoK} \alpha$ radiation, for which a graphite monochromator was used. Intensities were measured using an Apex2 detector at sample to detector distance of $40 \mathrm{~mm}$. The crystallographic cell was found using EVAL-CCD. ${ }^{[66]}$ The point group determination was followed by the determination of the position of all nonhydrogen atoms by direct methods using SIR2004 ${ }^{[67]}$ and refined in the WinGX software package ${ }^{[68]}$ using SHELX-97. ${ }^{[69]}$ Absorption corrections were performed using the SADABS program ${ }^{[70,71]}$. The refined cell constants and additional crystal data are given in Table S1. The non hydrogen atoms were easily localized after structure determination and subsequent Fourier analyses have revealed the position of the hydrogen atoms. The latter were introduced as riding with their relevant parent atoms. The refinements were performed using anisotropic thermal displacement parameters for all the non-hydrogen atoms.

\section{Synthesis of the complexes}

Preparation of $\left[\mathrm{Ru}(\mathrm{dbm})_{3}\right] \mathbf{1}$

$\left[\mathrm{Ru}(\mathrm{dbm})_{3}\right] \mathbf{1}$ was prepared via a slightly modified procedure taken from Endo et al. ${ }^{[48]}: \mathrm{RuCl}_{3}, x \mathrm{H}_{2} \mathrm{O}(1 \mathrm{~g}, 4.1 \mathrm{mmol}$ as $\mathrm{Ru})$ was solubilised in the solvent mixture ethanol/water $(100: 25,125 \mathrm{~mL})$ previously degassed with argon. The reaction mixture was stirred at $100^{\circ} \mathrm{C}$ and obtained a dark blue colour in $4-5 \mathrm{~h} .3 .3 \mathrm{~g}(14.7 \mathrm{mmol})$ of $\mathrm{dbm}$ were added to the cooled solution. $1 \mathrm{~h} 30$ after the addition of the ligand to the ruthenium blue solution, a portion of $\mathrm{KHCO}_{3}(0.78 \mathrm{~g}, 7.8 \mathrm{mmol})$ was added to the cooled solution, which had become green. The colour of the solution turned gradually from green to orange leaving a dark precipitate. Another portion of $\mathrm{KHCO}_{3}(0.75$ $\mathrm{g}, 7.5 \mathrm{mmol}$ ) was added $1 \mathrm{~h}$ after the first addition, at which point the solution was already orange. Each time $\mathrm{KHCO}_{3}$ is added, gas formation is observed. The solution was refluxed for an additional $2 \mathrm{~h}$. At the end of the reaction, the dark precipitate was filtered and washed with cold ethanol and pentane until the ligand spot was no longer visible on the TLC plate. The complex was purified using column chromatography on Silica with a mixture of cyclohexane/ $\mathrm{CH}_{2} \mathrm{Cl}_{2}$ (70:30). A black solid was obtained after evaporation with a yield of $47 \%$ (1.6 g). Mass spectroscopy (FAB, DCM, MNBA) m/z: $771 \mathrm{M}^{+}$(calc. 770.81), $548[\mathrm{M}-\mathrm{dbm}]^{+}$. IR (KBr) v/ $\mathrm{cm}^{-1} 1520$ $(\mathrm{C}=\mathrm{O}), 1598,1586$ and $1483(\mathrm{C}=\mathrm{C}) . \mathrm{CV}\left(\mathrm{DCM}, 0.1 \mathrm{M}\right.$ TBAH, 0.1 V.s ${ }^{-1}$, vs.SCE) $\mathrm{E}_{1 / 2}\left(\mathrm{Ru}^{\mathrm{III}} / \mathrm{Ru}^{\mathrm{II}}\right)=-0.615 \mathrm{~V},|\Delta \mathrm{E}|=0.068 \mathrm{~V}, \mathrm{E}_{1 / 2}\left(\mathrm{Ru}^{\mathrm{III}} / \mathrm{Ru}^{\mathrm{IV}}\right)=1.000$ $\mathrm{V},|\Delta \mathrm{E}|=0.076 \mathrm{~V}$. UV-Vis. spectroscopy $\left(\mathrm{DCM}, 4.67 \times 10^{-5} \mathrm{M}\right) \lambda / \mathrm{nm}$ $\left(\varepsilon / 10^{3} \mathrm{M}^{-1} . \mathrm{cm}^{-1}\right) 430$ (12.8), 330 (48.9), 258 (35.5). ${ }^{1} \mathrm{H}$ NMR $\left(\mathrm{CD}_{2} \mathrm{Cl}_{2}, \delta=\right.$ $5.32 \mathrm{ppm}) 11.94\left(12 \mathrm{H}, \mathrm{s}, \mathrm{H}_{\mathrm{c}}\right), 9.28\left(6 \mathrm{H}, \mathrm{t}, \mathrm{J}=7.0 \mathrm{~Hz}, \mathrm{H}_{\mathrm{a}}\right), 6.76(12 \mathrm{H}, \mathrm{d}, \mathrm{J}=$ $\left.7.0 \mathrm{~Hz}, \mathrm{H}_{\mathrm{b}}\right),-33.12\left(3 \mathrm{H}, \mathrm{s}, \mathrm{H}_{\mathrm{f}}\right) .{ }^{13} \mathrm{C} \mathrm{NMR}\left(\mathrm{CD}_{2} \mathrm{Cl}_{2}, \delta=53.7 \mathrm{ppm}\right) 135.64$ (b), 125.50 (a), 113.79 (c), 100.63 (d). 
Preparation of $\left[\mathrm{Ru}(\mathrm{dbm})_{2}\left(\mathrm{CH}_{3} \mathrm{CN}\right)_{2}\right] \mathrm{CF}_{3} \mathrm{SO}_{3} 4$.

$\left[\mathrm{Ru}(\mathrm{dbm})_{2}\left(\mathrm{CH}_{3} \mathrm{CN}\right)_{2}\right] \mathrm{CF}_{3} \mathrm{SO}_{3} 4$ was synthesized according to the procedure given by Baird I. R. et al. ${ }^{[50]}$ A particularly notable colour change from redbrown to green was observed. (Yield: $96 \%, 1 \mathrm{~g}$ ) Mass spectroscopy (FAB,

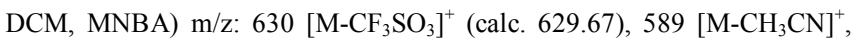
$548\left[\mathrm{M}-2 \mathrm{CH}_{3} \mathrm{CN}\right]^{+}$. IR $(\mathrm{KBr}) v / \mathrm{cm}^{-1} 1523(\mathrm{C}=\mathrm{O}), 1598,1587$ and 1484 $(\mathrm{C}=\mathrm{C}), 2325$ and $2297(\mathrm{C} \equiv \mathrm{N}), 2992$ and $2927(\mathrm{CH} \mathrm{sp} 3)$. CV (DCM, $0.1 \mathrm{M}$ TBAH, 0.1 V.s ${ }^{-1}$, vs.SCE) $\mathrm{E}_{1 / 2}\left(\mathrm{Ru}^{\text {III }} / \mathrm{Ru}^{\text {II }}\right)=0.150 \mathrm{~V},|\Delta \mathrm{E}|=0.063 \mathrm{~V}, \mathrm{E}_{\mathrm{ox}}=$ $1.724 \mathrm{~V}$. UV-Vis. spectroscopy (DCM, $\left.4.94 \times 10^{-5} \mathrm{M}\right) \lambda / \mathrm{nm}\left(\varepsilon / 10^{3} \mathrm{M}^{-1} . \mathrm{cm}^{-}\right.$ 1) 633 (1.8), 388 (11.9), 336 (37.6), 263 (20.9), 228 (16.2).

Preparation of $\left[\mathrm{Ru}(\mathrm{dbm})_{2}(\mathrm{acac})\right] 2$ and $\left[\mathrm{Ru}(\mathrm{dbm})(\mathrm{acac})_{2}\right] \mathbf{3}$

$\left[\mathrm{Ru}(\mathrm{dbm})_{2}(\mathrm{acac})\right] 2$ was prepared by two different procedures ( $c f$. scheme 1 and 2).

- First, the complex was prepared from $\left[\mathrm{Ru}(\mathrm{dbm})_{2}\left(\mathrm{CH}_{3} \mathrm{CN}\right)_{2}\right] \mathrm{CF}_{3} \mathrm{SO}_{3} 4(0.8$ g, $1.03 \mathrm{mmol})$ solubilised in a solvent mixture ethanol/water $(90: 10,100$ $\mathrm{mL})$ previously degassed with argon. Acac $(0.135 \mathrm{~mL}, 1.3 \mathrm{mmol})$ and $\mathrm{KHCO}_{3}(0.13 \mathrm{~g}, 1.3 \mathrm{mmol})$ were added. The reaction mixture was stirred at $100{ }^{\circ} \mathrm{C}$. The colour of the solution turned from green to pink-red in about 15 minutes after reflux. After 1 hour the TLC plates no longer showed the spot for $\left[\mathrm{Ru}(\mathrm{dbm})_{2}\left(\mathrm{CH}_{3} \mathrm{CN}\right)_{2}\right] \mathrm{CF}_{3} \mathrm{SO}_{3}$, and thus, the reaction was stopped. The solution was evaporated to dryness. To remove the solution's salts, the crude product was extracted with $c a .40 \mathrm{~mL}$ portions of dichloromethane and $c a .3 \times 20 \mathrm{~mL}$ portions of water. The extract was evaporated to dryness. Then it was purified by column chromatography on Silica with, first, toluene, and afterward, a mixture of hexane $/ \mathrm{CH}_{2} \mathrm{Cl}_{2}$ (70:30) to give black crystals (yield: $11 \%, 80 \mathrm{mg}$ ).

- In the second procedure, inspired by that given by Endo et al. ${ }^{[48]} \mathrm{RuCl}_{3}$, $x \mathrm{H}_{2} \mathrm{O}(2 \mathrm{~g}, 8.2 \mathrm{mmol})$ was solubilised in the solvent mixture ethanol/water $(125: 30,155 \mathrm{~mL})$ previously degassed with argon. The reaction mixture was stirred at $100{ }^{\circ} \mathrm{C}$ and obtained a dark blue colour in 4-5 h. At this time, $\mathrm{dbm}(3.7 \mathrm{~g}, 16.5 \mathrm{mmol})$ and acac $(0.844 \mathrm{~mL}, 8.2 \mathrm{mmol})$ were added to the cooled solution. TLC was used to check the reaction on Silica with toluene. The solution was refluxed for an additional 2 hours. Then, the mixture was cooled again and $\mathrm{KHCO}_{3}(1.25 \mathrm{~g}, 12.5 \mathrm{mmol})$ was added to the green solution. A release of gas was observed. During the night, the solution turned to orange and in the morning, it was cooled to add another portion of $\mathrm{KHCO}_{3}(1.23 \mathrm{~g}, 12.3 \mathrm{mmol})$. The solution was put under reflux yet again for $4 \mathrm{~h}$, and then the last portion of $\mathrm{KHCO}_{3}(1.24 \mathrm{~g}, 12.4 \mathrm{mmol})$ was added to the cooled solution. A black precipitate gradually appeared with the addition of $\mathrm{KHCO}_{3}$. The heating and the stirring were held constant for a second night. The reaction was stopped after 48 hours. The solvents were evaporated and the black precipitate purified using column chromatography on Silica with a mixture of hexane/ $\mathrm{CH}_{2} \mathrm{Cl}_{2}(60: 40)$. Three products were collected : first, $\left[\mathrm{Ru}(\mathrm{dbm})_{3}\right] \mathbf{1}$ (black powder, yield: $17 \%, 1.1 \mathrm{~g}$ ), second, $\left[\mathrm{Ru}(\mathrm{dbm})_{2}(\mathrm{acac})\right] 2$ (crimson powder, yield: $35 \%, 1.9 \mathrm{~g}$ ) and third, $\left[\mathrm{Ru}(\mathrm{dbm})(\mathrm{acac})_{2}\right] 3$ (dark red crystals, yield: $\left.4 \%, 0.16 \mathrm{~g}\right)$. [Ru(dbm) $\left.{ }_{2}(\mathrm{acac})\right]$ $2 \mathrm{C}_{35} \mathrm{H}_{29} \mathrm{O}_{6} \mathrm{Ru}$ (646.67): calcd. C, 65.0; H, 4.5; Ru, 15.6; found: $\mathrm{C}, 64.0 ; \mathrm{H}$, 4.7; Ru, 13.0. Mass spectroscopy (FAB, DCM, MNBA) m/z: $647 \mathrm{M}^{+}$(calc. 646.67), $548[\mathrm{M}-\mathrm{Acac}]^{+}, 424[\mathrm{M}-\mathrm{Dbm}]^{+}$. IR (KBr) $v / \mathrm{cm}^{-1} 1520(\mathrm{C}=\mathrm{O})$, e (NBS) was solubilised in dichloromethane and was added dropwise to the $0.1 \mathrm{~V} . s^{-1}$, vs.SCE $) \mathrm{E}_{1 / 2}\left(\mathrm{Ru}^{\mathrm{III}} / \mathrm{Ru}^{\mathrm{II}}\right)=-0.689 \mathrm{~V},|\Delta \mathrm{E}|=0.073 \mathrm{~V}$, $\mathrm{E}_{1 / 2}\left(\mathrm{Ru}^{\mathrm{III}} / \mathrm{Ru}^{\mathrm{IV}}\right)=0.995 \mathrm{~V},|\Delta \mathrm{E}|=0.076 \mathrm{~V}$. UV-Vis. spectroscopy (DCM, $\left.5.41 \times 10^{-5} \mathrm{M}\right) \lambda / \mathrm{nm}\left(\varepsilon / 10^{3} \mathrm{M}^{-1} . \mathrm{cm}^{-1}\right) 415(8.8), 332(34.8), 258(28.1) .{ }^{1} \mathrm{H}$ $\operatorname{NMR}\left(\mathrm{CD}_{2} \mathrm{Cl}_{2}, \delta=5.32 \mathrm{ppm}\right) 13,10\left(4 \mathrm{H}, \mathrm{s}, \mathrm{H}_{\mathrm{i}}\right), 12.04\left(4 \mathrm{H}, \mathrm{s}, \mathrm{H}_{\mathrm{c}}\right), 9.81(2 \mathrm{H}$, $\left.\mathrm{t}, \mathrm{J}=6.9 \mathrm{~Hz}, \mathrm{H}_{\mathrm{k}}\right), 9.60\left(2 \mathrm{H}, \mathrm{t}, \mathrm{J}=6.9 \mathrm{~Hz}, \mathrm{H}_{\mathrm{a}}\right), 6.95\left(4 \mathrm{H}, \mathrm{d}, \mathrm{J}=6.8 \mathrm{~Hz}, \mathrm{H}_{\mathrm{j}}\right)$, $6.42\left(4 \mathrm{H}, \mathrm{d}, \mathrm{J}=6.8 \mathrm{~Hz}, \mathrm{H}_{\mathrm{b}}\right),-0.80\left(6 \mathrm{H}, \mathrm{s}, \mathrm{H}_{\mathrm{l}}\right),-22.75\left(1 \mathrm{H}, \mathrm{s}, \mathrm{H}_{\mathrm{n}}\right),-37.02$ $\left(2 \mathrm{H}, \mathrm{s}, \mathrm{H}_{\mathrm{f}}\right) \cdot{ }^{13} \mathrm{C} \mathrm{NMR}\left(\mathrm{CD}_{2} \mathrm{Cl}_{2}, \delta=53.7 \mathrm{ppm}\right) 137,62(\mathrm{~b}), 137,20(\mathrm{j}), 124,09$ (k), 122,65 (a), 111,99 (i), 109,19 (d), 108,91 (c), 103,76 (h), -32,69 (1). [Ru(dbm)(acac $\left.)_{2}\right] 3 \mathrm{C}_{25} \mathrm{H}_{25} \mathrm{O}_{6} \mathrm{Ru}(522.53)$ : calcd. C, 57.5; H, 4.8; found: $\mathrm{C}$, 57.3 ; H, 4.9. Mass spectroscopy (FAB, DCM, MNBA) m/z: $523 \mathrm{M}^{+}$(calc. 522.53), $424[\mathrm{M}-\mathrm{Acac}]^{+}, 300[\mathrm{M}-\mathrm{Dbm}]^{+}$. IR (KBr) $v / \mathrm{cm}^{-1} 1520(\mathrm{C}=\mathrm{O})$, 1597 and $1483(\mathrm{C}=\mathrm{C}), 2919$ (CH sp3). CV (DCM, 0.1 M TBAH, 0.1 V.s ${ }^{-1}$, vs.SCE $) \mathrm{E}_{1 / 2}\left(\mathrm{Ru}^{\mathrm{III}} / \mathrm{Ru}^{\mathrm{II}}\right)=-0.767 \mathrm{~V},|\Delta \mathrm{E}|=0.078 \mathrm{~V}, \mathrm{E}_{1 / 2}\left(\mathrm{Ru}^{\mathrm{III}} / \mathrm{Ru}^{\mathrm{IV}}\right)=0.993$
$\mathrm{V},|\Delta \mathrm{E}|=0.081 \mathrm{~V}$. UV-Vis. spectroscopy (DCM, $\left.8.66 \times 10^{-5} \mathrm{M}\right) \lambda / \mathrm{nm}$ $\left(\varepsilon / 10^{3} \mathrm{M}^{-1} \cdot \mathrm{cm}^{-1}\right) 504$ (2.2), 404 (6.5), 335 (20.6), 262 (20.6), 229 (13.5). ${ }^{1} \mathrm{H}$ $\operatorname{NMR}\left(\mathrm{CD}_{2} \mathrm{Cl}_{2}, \delta=5.32 \mathrm{ppm}\right) 13.06\left(4 \mathrm{H}, \mathrm{s}, \mathrm{H}_{\mathrm{c}}\right), 9.94\left(2 \mathrm{H}, \mathrm{t}, \mathrm{J}=6.9 \mathrm{~Hz}, \mathrm{H}_{\mathrm{a}}\right)$, $6.64\left(4 \mathrm{H}, \mathrm{d}, \mathrm{J}=6.8 \mathrm{~Hz}, \mathrm{H}_{\mathrm{b}}\right),-2.46\left(6 \mathrm{H}, \mathrm{s}, \mathrm{H}_{\mathrm{p}}\right),-4.86\left(6 \mathrm{H}, \mathrm{s}, \mathrm{H}_{1}\right),-26.91(2 \mathrm{H}$, $\left.\mathrm{s}, \mathrm{H}_{\mathrm{n}}\right),-39.61\left(1 \mathrm{H}, \mathrm{s}, \mathrm{H}_{\mathrm{f}}\right),{ }^{13} \mathrm{C} \mathrm{NMR}\left(\mathrm{CD}_{2} \mathrm{Cl}_{2}, \delta=53.7 \mathrm{ppm}\right) 138.46(\mathrm{~b})$, 121.79 (a), 109.22 (d), 108.32 (c), -26.28 (1), -28.52 (p).

Preparation of $\left[\mathrm{Ru}(\mathrm{dbm})_{2}(\mathrm{acac}-\mathrm{I})\right] \mathbf{5}$ and $\left[\mathrm{Ru}(\mathrm{dbm})_{2}(\mathrm{acac}-\mathrm{Br})\right] \mathbf{6}$.

$\left[\mathrm{Ru}(\mathrm{dbm})_{2}(\mathrm{acac}-\mathrm{I})\right] \mathbf{5}$ was obtained by a direct substitution on the 3 -position of the acac ligand of $\left[\mathrm{Ru}(\mathrm{dbm})_{2}(\mathrm{acac})\right]$. $\left[\mathrm{Ru}(\mathrm{dbm})_{2}(\mathrm{acac})\right] 2(0.25 \mathrm{~g}, 0.4$ $\mathrm{mmol})$ was solubilised in toluene, and the solution was degassed with argon. $0.18 \mathrm{~g}(0.78 \mathrm{mmol})$ of $\mathrm{N}$-iodosuccinimide (NIS) was added and the mixture was stirred at r.t.. The solution was dark orange. After 1 hour, as no evolution appeared on the TLC plates (Silica, toluene), the mixture was refluxed. The solution became darker (black with red gleams). 1 hour after refluxing, $0.17 \mathrm{~g}(0.77 \mathrm{mmol})$ of NIS was added. 1 hour later a last portion of NIS ( $0.18 \mathrm{~g}, 0.79 \mathrm{mmol})$ was added. The reaction was stopped after 4 hours. To remove the excess iodine, $25 \mathrm{~mL}$ of an aqueous solution $(0.5 \mathrm{M})$ of sodium thiosulfate were added. Then, the mixture was extracted with $c a$. $5 \times 40 \mathrm{~mL}$ of toluene and $c a .4 \times 100 \mathrm{~mL}$ of distilled water to wash the organic phase. All of the extracted organic portions were consolidated and the toluene was evaporated. The crude product was purified using column chromatography on Silica with toluene. Dark purple crystals were obtained with a yield of $77 \%(0.2 \mathrm{~g}) . \mathrm{C}_{35} \mathrm{H}_{28} \mathrm{O}_{6} \mathrm{IRu}$ (772.57): calcd. C, 54.4; H, 3.7; I, 16.4; found: C, 53.8; H, 3.7; I, 16.9. Mass spectroscopy (FAB, DCM, MNBA) m/z: $773 \mathrm{M}^{+}$(calc. 772.57), 647 [M-I] $]^{+}, 548[\mathrm{M}-\mathrm{Acac}-\mathrm{I}]^{+}, 423[\mathrm{M}-$ Dbm-I $]^{+}$. IR (KBr) $v / \mathrm{cm}^{-1} 1509(\mathrm{C}=\mathrm{O}), 1598,1586$ and $1482(\mathrm{C}=\mathrm{C}), 2923$ and 2853 (CH sp3). CV (DCM, 0.1 M TBAH, 0.1 V.s ${ }^{-1}$, vs.SCE) $\mathrm{E}_{1 / 2}\left(\mathrm{Ru}^{\mathrm{II}} / \mathrm{Ru}^{\mathrm{II}}\right)=-0.613 \mathrm{~V},|\Delta \mathrm{E}|=0.073 \mathrm{~V}, \mathrm{E}_{1 / 2}\left(\mathrm{Ru}^{\mathrm{III}} / \mathrm{Ru}^{\mathrm{IV}}\right)=1.045 \mathrm{~V},|\Delta \mathrm{E}|$ $=0.074 \mathrm{~V}$. UV-Vis. spectroscopy $\left(\mathrm{DCM}, 4.92 \times 10^{-5} \mathrm{M}\right) \lambda / \mathrm{nm}\left(\varepsilon / 10^{3} \mathrm{M}^{-}\right.$ $\left.{ }^{1} . \mathrm{cm}^{-1}\right) 562$ (2.2), 414 (10.6), 331 (36.7), 257 (27.9), 228 (23.1). ${ }^{1} \mathrm{H}$ NMR $\left(\mathrm{CD}_{2} \mathrm{Cl}_{2}, \delta=5.32 \mathrm{ppm}\right) 12.45\left(4 \mathrm{H}, \mathrm{s}, \mathrm{H}_{\mathrm{i}}\right), 11.92\left(4 \mathrm{H}, \mathrm{s}, \mathrm{H}_{\mathrm{c}}\right), 9.83(2 \mathrm{H}, \mathrm{t}, \mathrm{J}=$ $\left.6.8 \mathrm{~Hz}, \mathrm{H}_{\mathrm{k}}\right), 9.60\left(2 \mathrm{H}, \mathrm{t}, \mathrm{J}=6.8 \mathrm{~Hz}, \mathrm{H}_{\mathrm{a}}\right), 6.55\left(4 \mathrm{H}, \mathrm{d}, \mathrm{J}=6.7 \mathrm{~Hz}, \mathrm{H}_{\mathrm{b}}\right), 6.52$ $\left(4 \mathrm{H}, \mathrm{d}, \mathrm{J}=6.7 \mathrm{~Hz}, \mathrm{H}_{\mathrm{j}}\right),-1.49\left(6 \mathrm{H}, \mathrm{s}, \mathrm{H}_{\mathrm{l}}\right),-41.08\left(2 \mathrm{H}, \mathrm{s}, \mathrm{H}_{\mathrm{f}}\right) .{ }^{13} \mathrm{C}$ NMR $\left(\mathrm{CD}_{2} \mathrm{Cl}_{2}, \delta=53.7 \mathrm{ppm}\right) 138.44$ (j), 136.86 (b), 123.43 (a), $122.24(\mathrm{k})$, 113.08 (d), 109.55 (c), 108.00 (i), 102.54 (h), 6.46 (l).

$\left[\mathrm{Ru}(\mathrm{dbm})_{2}(\mathrm{acac}-\mathrm{Br})\right] \mathbf{6}$ was also obtained by a direct substitution on the $3-$ position of the acac ligand of $\left[\mathrm{Ru}(\mathrm{dbm})_{2}(\mathrm{acac})\right]$. $\left[\mathrm{Ru}(\mathrm{dbm})_{2}(\mathrm{acac})\right] \mathbf{2}(0.36 \mathrm{~g}$, $0.55 \mathrm{mmol})$ was solubilised in dichloromethane, and the solution was degassed with argon. $0.1 \mathrm{~g}(0.56 \mathrm{mmol})$ of N-bromosuccinimide (NBS) was solubilised in dichloromethane and was added dropwise to the solution. The mixture was stirred at r.t. The solution gradually became darker (black with red gleams). The reaction was stopped after the entire addition of NBS, and the solution was evaporated to dryness. The crude product was purified using column chromatography on Silica with toluene. Black crystals were obtained with a yied of $89 \%(0.4 \mathrm{~g}) . \mathrm{C}_{35} \mathrm{H}_{28} \mathrm{O}_{6} \mathrm{BrRu}$ (725.57): calcd. C, 57.9; $\mathrm{H}, 3.9 ; \mathrm{Br}, 11.0$; found: $\mathrm{C}, 57.9 ; \mathrm{H}, 3.9 ; \mathrm{Br}, 11.0$. Mass spectroscopy (FAB, DCM, MNBA) m/z: $727 \mathrm{M}^{+}$(calc. 725.57), $647[\mathrm{M}-\mathrm{Br}]^{+}, 548[\mathrm{M}-$ Acac-Br] $]^{+}$. IR (KBr) $v / \mathrm{cm}^{-1} 1521(\mathrm{C}=\mathrm{O}), 1598,1586$ and $1483(\mathrm{C}=\mathrm{C}), 2923$ (CH sp3). CV (DCM, 0.1 M TBAH, 0.1 V.s ${ }^{-1}$, vs.SCE) $\mathrm{E}_{1 / 2}\left(\mathrm{Ru}^{\mathrm{III}} / \mathrm{Ru}^{\mathrm{II}}\right)=$ $0.608 \mathrm{~V},|\Delta \mathrm{E}|=0.074 \mathrm{~V}, \mathrm{E}_{1 / 2}\left(\mathrm{Ru}^{\mathrm{III}} / \mathrm{Ru}^{\mathrm{IV}}\right)=1.058 \mathrm{~V},|\Delta \mathrm{E}|=0.073 \mathrm{~V}$. UVVis. spectroscopy (DCM, $\left.5.17 \times 10^{-5} \mathrm{M}\right) \lambda / \mathrm{nm}\left(\varepsilon / 10^{3} \mathrm{M}^{-1} . \mathrm{cm}^{-1}\right) 556(2.4)$, 412 (11.6), 331 (41.0), 258 (30.6), 228 (22.8). ${ }^{1} \mathrm{H}$ NMR $\left(\mathrm{CD}_{2} \mathrm{Cl}_{2}, \delta=5.32\right.$ ppm) $12.38\left(4 \mathrm{H}, \mathrm{s}, \mathrm{H}_{\mathrm{i}}\right), 12.26\left(4 \mathrm{H}, \mathrm{s}, \mathrm{H}_{\mathrm{c}}\right), 9.79\left(2 \mathrm{H}, \mathrm{t}, \mathrm{J}=6.9 \mathrm{~Hz}, \mathrm{H}_{\mathrm{k}}\right), 9.67$ $\left(2 \mathrm{H}, \mathrm{t}, \mathrm{J}=6.9 \mathrm{~Hz}, \mathrm{H}_{\mathrm{a}}\right), 6.62\left(4 \mathrm{H}, \mathrm{d}, \mathrm{J}=6.7 \mathrm{~Hz}, \mathrm{H}_{\mathrm{j}}\right), 6.50\left(4 \mathrm{H}, \mathrm{d}, \mathrm{J}=6.7, \mathrm{H}_{\mathrm{b}}\right)$, $-1.76\left(6 \mathrm{H}, \mathrm{s}, \mathrm{H}_{\mathrm{l}}\right),-40.61\left(2 \mathrm{H}, \mathrm{s}, \mathrm{H}_{\mathrm{f}}\right) .{ }^{13} \mathrm{C}$ NMR $\left(\mathrm{CD}_{2} \mathrm{Cl}_{2}, \delta=53.7 \mathrm{ppm}\right)$ 138.32 (b), 137.03 (j), 123.57 (a), 122.42 (k), 112.33 (d), 110.15 (c), 107.82 (i), $102.73(\mathrm{~h}),-0.05$ (l)

Supporting Information X-ray crystallographic files in CIF format for 1-4 and 6 (CCDC 803933, 803944, 803947, 803948, 803955); ORTEP drawings of 2, 3 and 4; Table of crystallographic data for 1-4 and 6; Table of selected bond lengths and bond angles for 1-4 and 6; Cyclic 
Voltammetry of $\mathbf{1}, \mathbf{2}, 5$ and $6\left(\mathrm{CH}_{2} \mathrm{Cl}_{2}, 0.1 \mathrm{M}\right.$ TBAH, $\left.0.1 \mathrm{~V} \cdot \mathrm{s}^{-1}\right)$; UV-Vis spectra of complexes 1-3 in $\mathrm{CH}_{2} \mathrm{Cl}_{2}$; UV-Vis spectra of complexes 1, 2, 5, $\mathbf{6}$ in $\mathrm{CH}_{2} \mathrm{Cl}_{2} ;{ }^{1} \mathrm{H}$ NMR spectrum of complex 1- 3, 5, 6 in $\mathrm{CD}_{2} \mathrm{Cl}_{2} ;{ }^{13} \mathrm{C}$ NMR spectrum of complex 1- 3, 5, 6 in $\mathrm{CD}_{2} \mathrm{Cl}_{2}$.

\section{Acknowledgments}

The authors thank CNRS and the WPI (World Premier International) MANA (Materials Nanoarchitectonics) program for financial support. YB and XB thank the ANR-COSINUS program through the SAMSON (System for Adaptive Modeling and Simulation Of Nano-objects) project.

[1] D. Astruc, C. Ornelas, J. R. Aranzaes, J. Inorg. Organomet. Polym. Mater. 2008, 18, 4-17.

[2] V. Balzani, A. Credi, M. Venturi, Chem. Eur. J. 2008, 14, 26-39.

[3] J. W. Canary, S. Mortezaei, J. A. Liang, Coord. Chem. Rev. 2010, 254, 2249-2266.

[4] M. C. Dul, E. Pardo, R. Lescouezec, Y. Journaux, J. FerrandoSoria, R. Ruiz-Garcia, J. Cano, M. Julve, F. Lloret, D. Cangussu, C. L. M. Pereira, H. O. Stumpf, J. Pasan, C. Ruiz-Perez, Coord. Chem. Rev. 2010, 254, 2281-2296.

[5] V. A. Friese, D. G. Kurth, Curr. Opin. Colloid Interface Sci. 2009, 14, 81-93.

[6] J. K. H. Hui, M. J. MacLachlan, Coord. Chem. Rev. 2010, 254, 2363-2390.

[7] C. P. Myers, M. E. Williams, Coord. Chem. Rev. 2010, 254, 2416-2428.

[8] C. C. You, R. Dobrawa, C. R. Saha-Moller, F. Wurthner, in Supermolecular Dye Chemistry, Vol. 258, 2005, pp. 39-82.

[9] L. Grill, J. Phys.-Condens. Matter 2010, 22, 084023.

[10] M. Yu, W. Xu, Y. Benjalal, R. Barattin, E. Laegsgaard, I. Stensgaard, M. Hliwa, X. Bouju, A. Gourdon, C. Joachim, T. R. Linderoth, F. Besenbacher, Nano Research 2009, 2, 254-259.

[11] T. Zambelli, S. Goudeau, J. Lagoute, A. Gourdon, X. Bouju, S. Gauthier, Chemphyschem 2006, 7, 1917-1920.

[12] P. J. Low, Dalton Trans. 2005, 2821-2824.

[13] C. J. Villagomez, O. Guillermet, S. Goudeau, F. Ample, H. Xu, C. Coudret, X. Bouju, T. Zambelli, S. Gauthier, J. Chem. Phys. 2010, 132, 074705 .

[14] B. Calmettes, S. Nagarajan, A. Gourdon, Y. Benjalal, X. Bouju, M. Abel, L. Porte, R. Coratger, J. Phys. Chem. C 2009, 113, 21169-21176.

[15] O. Guillermet, E. Niemi, S. Nagarajan, X. Bouju, D. Martrou, A. Gourdon, S. Gauthier, Angew. Chem. Int. Ed. 2009, 48, 19701973.

[16] C. J. Villagomez, T. Zambelli, S. Gauthier, A. Gourdon, C. Barthes, S. Stojkovic, C. Joachim, Chem. Phys. Lett. 2007, 450, 107-111.

[17] X. Lu, K. W. Hipps, X. D. Wang, U. Mazur, J. Am. Chem. Soc. 1996, 118, 7197-7202.

[18] M. Lastapis, M. Martin, D. Riedel, L. Hellner, G. Comtet, G. Dujardin, Science 2005, 308, 1000-1003.

[19] L. Lafferentz, F. Ample, H. Yu, S. Hecht, C. Joachim, L. Grill, Science 2009, 323, 1193-1197.

[20] M. S. Alam, M. Stocker, K. Gieb, P. Muller, M. Haryono, K. Student, A. Grohmann, Angew. Chem. Int. Ed. 2010, 49, 11591163.

[21] S. Guo, S. A. Kandel, J. Phys. Chem. Lett. 2010, 1, 420-424.

[22] Y. H. Lu, R. Quardokus, C. S. Lent, F. Justaud, C. Lapinte, S. A. Kandel, J. Am. Chem. Soc. 2010, 132, 13519-13524.
[23] Z. Q. Wei, S. Guo, S. A. Kandel, J. Phys. Chem. B 2006, 110, 21846-21849.

[24] K. Petukhov, M. S. Alam, H. Rupp, S. Stromsdorfer, P. Muller, A. Scheurer, R. W. Saalfrank, J. Kortus, A. Postnikov, M. Ruben, L. K. Thompson, J. M. Lehn, Coord. Chem. Rev. 2009, 253, 2387-2398.

[25] P. Albores, L. D. Slep, L. S. Eberlin, Y. E. Corilo, M. N. Eberlin, G. Benitez, M. E. Vela, R. C. Salvarezza, L. M. Baraldo, Inorg. Chem. 2009, 48, 11226-11235.

[26] P. R. Andres, R. Lunkwitz, G. R. Pabst, K. Bohn, D. Wouters, S. Schmatloch, U. S. Schubert, Eur. J. Org. Chem. 2003, 37693776.

[27] A. Carella, C. Coudret, G. Guirado, G. Rapenne, G. Vives, J. P. Launay, Dalton Trans. 2007, 177-186.

[28] E. Figgemeier, L. Merz, B. A. Hermann, Y. C. Zimmermann, C. E. Housecroft, H. J. Guntherodt, E. C. Constable, J. Phys. Chem. B 2003, 107, 1157-1162.

[29] V. Ganesh, V. Lakshminarayanan, J. Phys. Chem. B 2005, 109, 16372-16381.

[30] E. Hubner, N. V. Fischer, F. W. Heinemann, U. Mitra, V. Dremov, P. Muller, N. Burzlaff, Eur. J. Inorg. Chem. 2010, 4100-4109.

[31] L. Latterini, G. Pourtois, C. Moucheron, R. Lazzaroni, J. L. Bredas, A. Kirsch-De Mesmaeker, F. C. De Schryver, Chem. Eur. J. 2000, 6, 1331-1336.

[32] K. Liu, X. H. Wang, F. S. Wang, Acs Nano 2008, 2, 2315-2323.

[33] L. C. Mayor, A. Saywell, G. Magnano, C. J. Satterley, J. Schnadt, J. N. O'Shea, J. Chem. Phys. 2009, 130, 164704.

[34] K. Seo, A. V. Konchenko, J. Lee, G. S. Bang, H. Lee, J. Am. Chem. Soc. 2008, 130, 2553-2559.

[35] G. Vives, G. Rapenne, Tetrahedron 2008, 64, 11462-11468.

[36] G. Vives, J. M. Tour, Acc. Chem. Res. 2009, 42, 473-487.

[37] I. R. Baird, S. J. Rettig, B. R. James, K. A. Skov, Can. J. Chem. 1999, 77, 1821-1833.

[38] T. Hashimoto, A. Endo, N. Nagao, G. P. Sato, K. Natarajan, K. Shimizu, Inorg. Chem. 1998, 37, 5211-5220.

[39] Y. Hoshino, S. Higuchi, J. Fiedler, C. Y. Su, A. Knodler, B. Schwederski, B. Sarkar, H. Hartmann, W. Kaim, Angew. Chem. Int. Ed. 2003, 42, 674-677.

[40] M. Maruyama, N. Sonoyama, Y. Kaizu, J. Phys. Chem. 1994, 98, 5332-5337.

[41] H. Sato, T. Taniguchi, A. Nakahashi, K. Monde, A. Yamagishi, Inorg. Chem. 2007, 46, 6755-6766.

[42] J. Tamura, Y. Satsu, D. Fukuhara, K. Shimizu, G. P. Sato, Inorg. Chim. Acta 1995, 236, 37-42.

[43] S. E. Grillo, H. Tang, C. Coudret, S. Gauthier, Chem. Phys. Lett. 2002, 355, 289-293.

[44] S. Stepanow, N. Lin, J. V. Barth, J. Phys.-Condens. Matter 2008 , 20, 184002 .

[45] F. Chiaravalloti, L. Gross, K. H. Rieder, S. M. Stojkovic, A. Gourdon, C. Joachim, F. Moresco, Nature Mat. 2007, 6, 30-33.

[46] E. Abad, Y. J. Dappe, J. I. Martinez, F. Flores, J. Ortega, J. Chem. Phys. 2011, 134, 044701.

[47] A. Endo, M. Kajitani, M. Mukaida, K. Shimizu, G. P. Sato, Inorg. Chim. Acta 1988, 150, 25-34.

[48] A. Endo, K. Shimizu, G. P. Sato, M. Mukaida, Chem. Lett. 1984, $437-440$

[49] Y. Kasahara, Y. Hoshino, K. Shimizu, G. P. Sato, Chem. Lett. 1990, 381-384. 
[50] I. R. Baird, B. R. Cameron, R. T. Skerlj, Inorg. Chim. Acta 2003, [61] $353,107-118$.

[51] A. Endo, K. Shimizu, G. P. Sato, Chem. Lett. 1985, 581-584.

[52] Y. Kasahara, Y. Hoshino, M. Kajitani, K. Shimizu, G. P. Sato, Organometallics 1992, 11, 1968-1971.

[53] S. Munery, J. Jaud, J. Bonvoisin, Inorg. Chem. Commun. 2008, $11,975-977$.

[54] H. H. Nguyen, N. Hoang, U. Abram, Transit. Met. Chem., 35, 89-93.

[55] P. Wang, J. E. Miller, L. M. Henling, C. L. Stern, N. L. Frank, A. L. Eckermann, T. J. Meade, Inorg. Chem. 2007, 46, 9853-9862.

[56] F. Ample, C. Joachim, Surf. Sci. 2006, 600, 3243.

[57] K. A. Jorgensen, R. Hoffmann, J. Am. Chem. Soc. 1986, 108, 1867-1876

[58] P. Sautet, C. Joachim, Phys. Rev. B. 1988, 38, 12238.

[59] M. Yu, N. Kalashnyk, R. Barattin, Y. Benjalal, M. Hliwa, X. Bouju, A. Gourdon, C. Joachim, E. Laegsgaard, F. Besenbacher, T. R. Linderoth, Chem. Comm. 2010, 46, 5545-5547.

[60] T. Choi, S. Bedwani, A. Rochefort, C. Y. Chen, A. J. Epstein, J. A. Gupta, Nano Letters 2010, 10, 4175-4180.
[61] U. G. E. Perera, H. J. Kulik, V. Iancu, L. da Silva, S. E. Ulloa, N. Marzari, S. W. Hla, Phys. Rev. Lett. 2010, 105, 106601.

[62] G. D. Scott, D. Natelson, Acs Nano 2010, 4, 3560-3579.

[63] D. Chylarecka, C. Wackerlin, T. K. Kim, K. Muller, F. Nolting, A. Kleibert, N. Ballav, T. A. Jung, J. Phys. Chem. Lett. 2010, 1, 1408-1413.

[64] S. Loth, M. Etzkorn, C. P. Lutz, D. M. Eigler, A. J. Heinrich, Science 2010, 329, 1628-1630.

[65] R. Wiesendanger, Rev. Mod. Phys. 2009, 81, 1495-1550.

[66] A. J. M. Duisenberg, Utrecht University, The Netherlands (Utrecht), 1998.

[67] M. C. Burla, R. Caliandro, M. Camalli, B. Carrozzini, G. L. Cascarano, L. de Caro, C. Giacovazzo, G. Polidori, R. Spagna, J. Appl. Cryst. 2005, 38, 381-388.

[68] L. J. Farrugia, J. Appl. Cryst. 1999, 32, 837-838.

[69] G. M. Sheldrick, Acta Cryst. 2008, A64, 112-122.

[70] Bruker, Madison, Wisconsin, USA 2001.

[71] G. M. Sheldrick, University of Göttingen, Germany 1996.

Received: ((will be filled in by the editorial staff)) Published online: ((will be filled in by the editorial staff)) 


\section{Entry for the Table of Contents}

UHV-STM on Ruthenium Complexes

Experimental (top) and EHMO-ESQC calculated (bottom) STM image of $\mathrm{Ru}(\mathrm{dbm})_{3}$ adsorbed on $\mathrm{Ag}(111)$ surface at liquid helium temperature

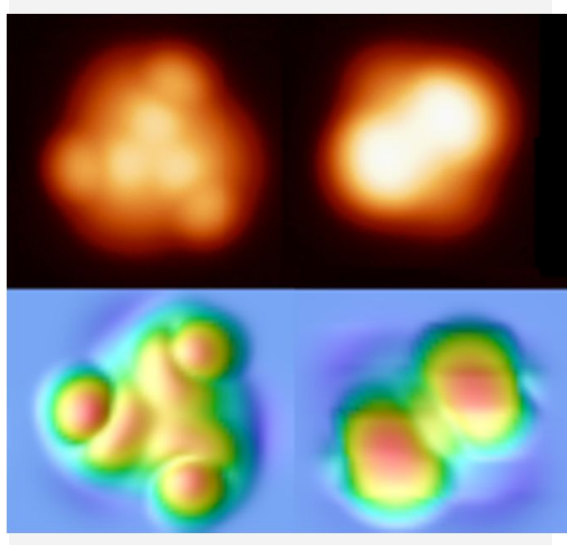

Sabrina Munery, Nicolas RatelRamond, Youness Benjalal, Loranne Vernisse, Olivier Guillermet, Xavier Bouju, Roland Coratger and Jacques Bonvoisin*

Synthesis and characterization of a series of ruthenium tris( $\beta$-diketonato) complexes with UHV-STM

investigation and numerical calculations

Keywords: Ruthenium, $\beta$-diketonato complex, mixed-ligand, X-Ray structure, low Temperature STM 